(D) Lerzan Doğan,

(1) Nazire Afşar,

(D) Dilaver Kaya,

(1) Zeynep Tuğçe Sarıkaya,

(1) Orkhan Mammadov,

(1) Canan Akıncı,

(1) Şahika Bolsoy Deveci,

(D) Filiz Tüzüner,

(1) Fatma Elif Gülek,

(1) Simten Demirel Kaya,

(1) Bülent Güçyetmez,

(D) Alp Dinçer,

(1) Sesin Kocagöz,

(D İbrahim Özkan Akıncı

Received/Geliş Tarihi : : 17.06.2021

Accepted/Kabul Tarihi : 27.10.2021

${ }^{\circ}$ Copyright 2021 by Turkish Society of Intensive Care Turkish Journal of Intensive Care published by Galenos Publishing House.

Lerzan Doğan, Orkhan Mammadov,

Simten Demirel Kaya

Acıbadem Altunizade Hospital, Clinic of Intensive

Care, Istanbul, Turkey

Nazire Afşar, Dilaver Kaya,

Acıbadem Mehmet Ali Aydınlar University Faculty of

Medicine, Department of Neurology, Istanbul, Turkey

Zeynep Tuğçe Sarıkaya, Bülent Güçyetmez

Acıbadem Mehmet Ali Aydınlar University Faculty

of Medicine, Department of Anesthesiology and

Reanimation, Istanbul, Turkey

Canan Akıncı

Acıbadem Fulya Hospital, Clinic of Intensive Care, Istanbul, Turkey

Şahika Bolsoy Deveci

Acıbadem Maslak Hospital, Clinic of Intensive Care,

Istanbul, Turkey

Filiz Tüzüner, Fatma Elif Gülek

Acıbadem Taksim Hospital, Clinic of Anesthesiology

and Reanimation, Istanbul, Turkey

Fatma Elif Gülek

Acıbadem Kozyatağı Hospital, Clinic of Anesthesiology and Reanimation, Istanbul, Turkey

Alp Dinçer

Acıbadem Mehmet Ali Aydınlar University Faculty of Medicine, Department of Radiology, Istanbul, Turkey

Sesin Kocagöz

Acıbadem Mehmet Ali Aydınlar University Faculty

of Medicine, Department of Infectious Disease and

Clinical Microbiology, Istanbul, Turkey

Ibrahim Özkan Akıncı

Acıbadem Healthcare Group, Intensive

Care Coordinator, Istanbul Turkey

Lerzan Doğan MD, (凶),

Acıbadem Altunizade Hospital, Clinic of Intensive

Care, Istanbul, Turkey

E-mail : Iredzheb@gmail.com

Phone : : +90216 6494444

ORCID ID : orcid.org/0000-0002-1456-4072

\section{Potential Prognostic Predictors for Coronavirus Disease-2019-related Impaired Consciousness in Patients with Critical IIInesses}

\author{
Kritik Hastalarda Koronavirüs Hastalığı-2019 \\ Illişkili Bilinç Bozukluğunun Potansiyel Prognostik \\ Faktörlerinin Belirlenmesi
}

ABSTRACT Objective: Central nervous system involvement in patients with coronavirus disease-2019 (COVID-19) is associated with increased morbidity and mortality. The assessment of neurological symptoms in patients with critical illnesses, who are mechanically ventilated under deep sedation is challenging, which means doctors could be unaware of such symptoms until patients reach the weaning stage. Thus, this study aimed to identify potential prognostic predictors for COVID-19-related impaired consciousness in patients with critical illnesses.

Materials and Methods: This retrospective, multicenter, and observational cohort study was conducted among patients with COVID-19 who were admitted to the intensive care units of five hospitals between March 11, 2020, and September 18, 2020. The patient population was analyzed in two groups-cases with impaired consciousness and cases without impaired consciousness. Results: Patients with impaired consciousness were found to be significantly younger $(p=0.001)$ and to exhibit significantly more laboratory abnormalities, such as high ferritin ( $p=0.003), C$-reactive protein $(p=0.001)$, procalcitonin $(p=0.019)$, and $D$-dimer $(p=0.001)$ levels. Additionally, pathological magnetic resonance imaging findings were detected in 14 of $29(48 \%)$ patients with impaired consciousness.

Conclusion: All patients with severe COVID-19 should be screened for signs of hyperinflammation due to the associated risk of neurological complications. The early detection of at-risk cases and the prompt initiation of specific treatment should result in better disease outcomes.

Keywords: COVID-19, neurological complications, inflammatory markers, hyperinflammation

ÖZ Amaç: Koronavirüs hastalığı-2019'un (COVID-19) neden olduğu merkezi sinir sistemi tutulumu, artan morbidite ve mortalite ile ilişkili bulunmuştur. Derin sedatize ve mekanik ventilasyon desteğ uygulanan yoğun bakım hastalarında nörolojik semptomları değerlendirmek ciddi bir zorluktur, bu nedenle ventilatörden ayırma aşamasına gelene kadar yoğun bakım hekimi bu semptomlardan habersiz kalabilmektedir. Çalışmanın amacı, kritik yoğun bakım hastalarında COVID-19 ilişkili bilinç bozukluğu için potansiyel prognostik prediktörlerin belirlenmesidir.

Gereç ve Yöntem: Çalışma retrospektif, çok merkezli ve gözlemsel olarak dizayn edilmiştir. Beş hastanenin yoğun bakım ünitelerine 11 Mart 2020 ve 18 Eylül 2020 tarihleri arasında kabul edilen COVID-19 hastaları dahil edilmiştir. Hastalar iki grupta değerlendirilmiştir: Bilinç bozukluğu olan ve bilinç bozukluğu olmayan hastalar.

Bulgular: Bilinç bozukluğu olan hastaların yaş ortalaması daha düşük $(p=0,001)$ ve daha fazla laboratuvar anormalliğine sahip bulunmuștur; ferritin $(p=0,003), C$-reaktif protein seviyeleri $(p=0,001)$, prokalsitonin $(p=0,019)$ ve D-dimer $(p=0,001)$. Ayrıca bilinç bozukluğu olan 29 hastanın 14'ünde (\%48) patolojik manyetik rezonans görüntüleme bulguları tespit edildi.

Sonuç: Yoğun bakımda COVID-19 hastaları nörolojik komplikasyon riskini belirlemek için hiperenflamasyon belirtileri açısından taranmalıdır. Erken tanı ve spesifik tedavinin başlatılması ile daha iyi sonuçlar alınabilecektir.

Anahtar Kelimeler: COVID-19, nörolojik komplikasyon, enflamasyon markerları, hiperenflamasyon 


\section{Introduction}

Central nervous system involvement in patients with coronavirus disease-2019 (COVID-19) is associated with increased morbidity and mortality (1), although the mechanisms underlying COVID-19-related neurological complications are not yet fully understood $(2,3)$. The expectation that most of the world's population will have been infected with COVID-19 before herd immunity develops indicates that the overall number of patients with neurological complications due to the disease could ultimately be very high. In light of this, supporting the development and manufacture of vaccines should be considered a priority because any delay to the vaccine rollout will result in additional deaths (4). In addition, given the ongoing nature of the COVID-19 pandemic, clinicians require accurate data to devise effective medical treatments for the disease and its complications (5). The assessment of neurological symptoms in critically ill patients who are mechanically ventilated and under deep sedation is challenging, which means that doctors could be unaware of such symptoms until patients reach the weaning stage.

Based on the above, the present study sought to identify potential prognostic predictors for COVID-19-related impaired consciousness in critically ill patients.

\section{Materials and Methods}

This retrospective, multicenter, observational cohort study was conducted among COVID-19 patients admitted to the intensive care units (ICUs) of five hospitals between March 11, 2020, and September 18, 2020. The study was approved by both the Republic of Turkey Ministry of Health and the Ethics Committee of Acıbadem University (decision no: 2020-09/12, date: 21.05.2020). The inclusion criteria for the study were as follows: patients $>18$ years old, all invasively mechanically ventilated, with an ICU stay longer than four days. Moreover, the exclusion criteria were as follows: patients $<18$ years old, patients administered only non-invasive mechanical ventilation, and patients with an ICU stay of less than four days (Figure 1).

The patients' clinical course was reviewed and data were collected concerning their age, sex, comorbidities, neurological findings, laboratory findings [including cerebrospinal fluid (CSF) analysis and inflammatory markers], and neuroimaging findings [computed tomography or magnetic resonance imaging (MRI)].
At the five ICUs, which were controlled by the same main intensivist, all COVID-19 patients were routinely treated in accordance with the Surviving Sepsis Campaign's COVID-19 treatment guidelines (6). More specifically, lung-protective ventilation strategies were used to limit the driving pressure and restrict both the tidal volume and plateau pressure while providing relatively high positive end-expiratory pressure. In addition, when respiratory acidosis and hypoxia persisted, early prone positioning ventilation was applied.

All COVID-19 patients also received the same sedation strategy. Due to the likelihood of the disease-causing acute respiratory distress syndrome (ARDS), deep sedation was used to improve both patients' tolerance of mechanical ventilation and patient-ventilator synchrony. To achieve deep sedation, a combination of midazolam and fentanyl was used as part of a sedation protocol, started with lower doses and titrate utilizing the Richmond Agitation Sedation scale to target standardized goals. Midazolam was only applied during the first few days of high-pressure ventilator support, and it was discontinued as soon as possible. When oxygenation was normalized, the chest $\mathrm{X}$-rays showed better aeration, and the infectious markers were almost normalized, ventilatory support was gradually withdrawn, it was ensured that there were no underlying metabolic disorders, and sedation was gradually reduced before being stopped. As deep sedation was applied, the patients waited 48 hours for residual sedation.

After 48 hours, if unresponsiveness to stimulation or refractory agitation were noted despite the treatment and no other explanation could be found, both situations were accepted as impaired consciousness. In those patients, neuroimaging, including diffusion-weighted and contrastenhanced MRI series, was performed following neurology consultation. For patients with pathological MRI findings, such as cortical signal abnormalities compatible with meningoencephalitis, a lumbar puncture (LP) was performed where possible. The patient population was analyzed in two groups, namely cases with impaired consciousness and cases without impaired consciousness (Figure 1).

\section{Statistical Analysis}

All data were presented as the mean, standard deviation, median, and interquartile range according to the distribution of the values. A t-test and a One-Way ANOVA were used for both groups' analyses. A multivariate binary logistic regression model and the backward elimination method were used to determine the patients' neurological 
symptoms. A p-value $<0.05$ was considered to be statistically significant. All of the statistical analyses in this study were performed using Statistical Package for the Social Sciences version 23.0 software for Windows (IBM Corp., Armonk, NY, USA).

\section{Results}

A total of 115 ICU patients were admitted to our 5 ICUs. Sixty seven of them were included in the study (Figure 1). Of these, 62 (92.5\%) were discharged to a ward, 5 (7.5\%) did not survive. All the patient demographic and clinical characteristics are shown in Table 1. Patients with impaired consciousness were found significantly younger $(p=0.001)$ than patients without impaired consciousness, with a median age of 55 vs 77 years. The two groups of patients had the similar mortality rate $(p=0.433)$ and ICU stay $(p=0.100)$.

Pathological MRI findings were detected in 14 of 29 (48\%) patients with impaired consciousness. In 11 of 29 patients (38\%), MRI showed cortical signal abnormalities. Other MRI findings included one patient with acute cerebrovascular disease $(2.7 \%)$, two patients with hypoxic-ischaemic brain injury $(5.4 \%)$, and one patient with acute transverse sinus thrombosis (2.7\%). CSF analysis showed normal glucose and high protein levels; the cell count, lgG index, and albumin were within normal limits, and reverse transcriptase-polymerase chain reaction (RT-PCR) was negative for common respiratory viruses and severe acute respiratory syndrome coronavirus 2 (SARS-CoV-2). Oligoclonal bands were negative in all cases. However, RT-PCR taken from respiratory samples was positive for SARS-CoV-2.

Patients with impaired consciousness had significantly more laboratory abnormalities than patients without

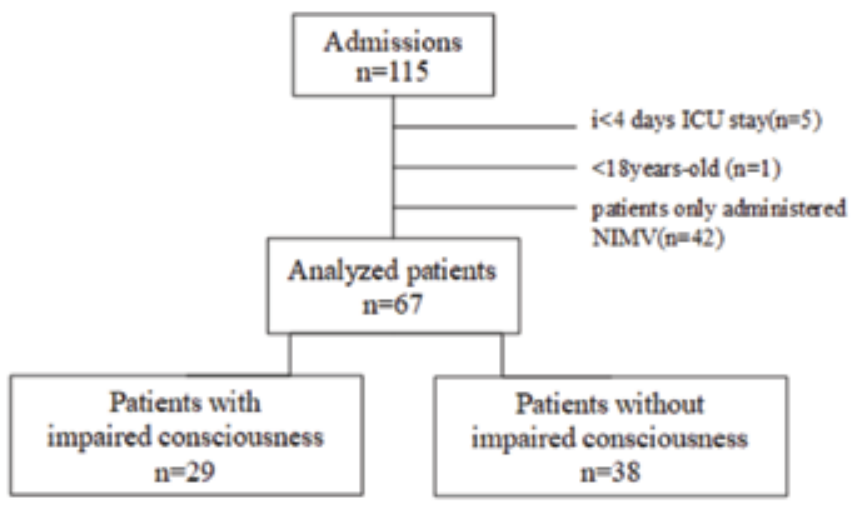

Figure 1. Flowchart of patient inclusion

ICU: Intensive care unit, NIMV: non-invasive mechanical ventilation impaired consciousness, such as high ferritin $(p=0.003)$, C-reactive protein (CRP) levels $(p=0.001)$, procalcitonin $(p=0.019)$, and D-dimer $(p=0.001)$ (Table 1). We carried out a multivariate logistic regression model for the likelihood of neurologic impairment. According to cut-off values, age, D-dimer, ferritin, CRP, procalcitonin, a dose of midazolam, durations of midazolam, and fentanyl administrations were added to the multivariate binary logistic regression model (Table 2). The Backward method was used in the regression model and it was not found a significant relationship between the likelihood of neurologic impairment and each of age, CRP, and fentanyl administrations (Table 3).

Even severity of disease scores in ICU admission and their ventilation parameters was found to be similar, patients with impaired consciousness required deeper sedation. Higher doses of sedatives were given to help attenuate agitation associated with mechanical ventilation $(p=0.005)$.

\section{Discussion}

It is challenging for intensivists to assess the neurological complications associated with COVID-19 in patients admitted to the ICU due to the requirement for deep sedation in cases of ARDS, which means that doctors could remain unaware of such neurological symptoms until patients reach the weaning stage. The present results indicated that the patients' age; their ferritin, D-dimer, CRP, and procalcitonin levels; and the requirement for deeper sedation might all be valuable prognostic indicators of impaired consciousness as a result of COVID-19.

Patients with suspected neurological complications must be aggressively investigated, as any delay in treatment could result in permanent neurological sequelae or even death. Although neuroimaging is not specifically designed for investigating cranial infections, it represents a useful way to document the extent of any neurological involvement, which is one of the key markers that determine prognosis (7). While neurological complications were identified at the weaning stage in the present study, this does not mean that $\mathrm{MRI}$ findings only come to prominence during the weaning period. Indeed, due to the use of deep sedation, it is possible that such complications were notified late. After the retrospectively obtained statistics had been analyzed, it was determined that the patients with neurological complications had required deeper sedation, which can be considered a predictor of neurological complications, especially when 
accompanied by laboratory abnormalities. In some patients, individual responses to the disease may never be reflected in the MRI findings. In addition, if neurological involvement is suspected, so long as it is not contraindicated, the use of LP should always be considered. The present results concerning the patients' CSF point toward an autoimmune/ antibody-mediated involvement hypothesis regarding both the meninges and the cerebral parenchyma, as mentioned in a previous report $(3,8-12)$.

\begin{tabular}{|c|c|c|c|}
\hline & \begin{tabular}{|l|} 
Patients with \\
impaired consciousness \\
$(n=29)$
\end{tabular} & $\begin{array}{l}\text { Patients without impaired } \\
\text { consciousness } \\
(n=38)\end{array}$ & P \\
\hline Age, years & $55(46-67)$ & $72(60-82)$ & $<0.001$ \\
\hline Male, n (\%) & $23(79.3)$ & $28(73.7)$ & 0.593 \\
\hline APACHE-II & $12(9.5-16)$ & $15(11-20.5)$ & 0.085 \\
\hline Bodyweight & 85.83 & 84.18 & 0.532 \\
\hline \multicolumn{4}{|l|}{ Comorbidities } \\
\hline Hypertension & 15 (40.54\%) & $20(25,64 \%)$ & \multirow{6}{*}{0.501} \\
\hline Diabetes & $10(27 \%)$ & $11(14.10 \%)$ & \\
\hline Chronic kidney & $2(5.4 \%)$ & $5(6.41 \%)$ & \\
\hline Malignancy & $3(8.11 \%)$ & $3(3.85 \%)$ & \\
\hline CVD & $4(10.81 \%)$ & $9(11.54 \%)$ & \\
\hline Autoimmune disease & $2(5.40 \%)$ & 0 & \\
\hline \multicolumn{4}{|l|}{ Ventilation } \\
\hline $\mathrm{FiO}_{2}$ (max) & $70(50-100)$ & $77.5(60-100)$ & 0.543 \\
\hline $\mathrm{PaO}_{2}$ (max) & $96(73-115)$ & $95(63-125)$ & 0.904 \\
\hline $\mathrm{PaO}_{2} / \mathrm{FiO}_{2}$ & $137(86-208)$ & $138(89-203)$ & 0.889 \\
\hline \multicolumn{4}{|l|}{ Laboratory findings } \\
\hline Lymphocyte count & $0.50(0.26-0.89)$ & $0.56(0.37-1.09)$ & 0.299 \\
\hline C-reactive protein, (mg/dL) & $29 \pm 15$ & $18 \pm 10$ & $<0.001$ \\
\hline Procalcitonin, (ng/mL) & $2.1(1.1-4.8)$ & $(0.3-2.5)$ & 0.019 \\
\hline D-dimer, (mg/L) & $5.8(4.6-10)$ & $3.4(1.8-4.7)$ & $<0.001$ \\
\hline Ferritin, $(\mathrm{ng} / \mathrm{mL})$ & $1,650(1,102-2,802)$ & $762(304-1,504)$ & 0.003 \\
\hline Lactate dehydrogenase, $(\mathrm{U} / \mathrm{L})$ & $435(337-611)$ & $365(244-451)$ & 0.059 \\
\hline Creatinine, (mg/dL) & $1.2(0.9-2.6)$ & $1.3(0.9-3.1)$ & 0.552 \\
\hline Blood urea, (mg/dL) & $89(56-160)$ & $90(49-219)$ & 0.781 \\
\hline \multicolumn{4}{|l|}{ Administered sedation } \\
\hline Duration of fentanyl administration, days & $10(8-12)$ & $8(7-12)$ & 0.01 \\
\hline Duration of midazolam administration, days & $9(8-10)$ & $6(5-10)$ & 0.007 \\
\hline Total dose of fentanyl, (mcg/kg) & $191 \pm 65$ & $170 \pm 55$ & 0.153 \\
\hline Total dose of midazolam, $(\mathrm{mg} / \mathrm{kg})$ & $13.7 \pm 2.8$ & $11.3 \pm 4.7$ & 0.012 \\
\hline \multicolumn{4}{|l|}{ Other characteristics, n (\%) } \\
\hline Persistent fever $\left(>39^{\circ} \mathrm{C}\right)$ & $13(44.8)$ & $13(34.2)$ & 0.377 \\
\hline Vasoactive agent & $12(41.4)$ & $12(31.6)$ & 0.407 \\
\hline Length of ICU stay, days & $17(13-21)$ & $14(11-18)$ & 0.100 \\
\hline Mortality, n (\%) & $3(10.3)$ & $2(5.3)$ & 0.433 \\
\hline
\end{tabular}




\begin{tabular}{|l|l|l|l|}
\hline \multicolumn{2}{|l|}{ Table 2. Cut-off values for likelihood of neurologic impairment } & Cut-off values & AUC (95\% Cl) \\
\hline Variables & $<66$ & $0.81(0.69-0.90)$ & p \\
\hline Age & $\geq 4.5$ & $0.76(0.63-0.89)$ & $<0.001$ \\
\hline D-dimer, (ug/mL) & $\geq 1,150$ & $0.73(0.59-0.86)$ & 0.001 \\
\hline Ferritin, (ng/mL) & $\geq 22.7$ & $0.72(0.59-0.85)$ & 0.003 \\
\hline C-reactive protein, (mg/dL) & $\geq 12.2$ & $0.69(0.57-0.82)$ & 0.003 \\
\hline Dose of midazolam (mg/kg) & $\geq 7.5$ & $0.69(0.56-0.82)$ & 0.007 \\
\hline Duration of midazolam administration, (days) & $\geq 8.5$ & $0.68(0.55-0.82)$ \\
\hline Duration of fentanyl administration, (days) & $\geq 1.62$ & $0.67(0.54-0.80)$ \\
\hline Procalcitonin, (ng/mL) & & 0.010 \\
\hline AUc: Area of under curve, Cl: confidence interval & & 0.019 \\
\hline
\end{tabular}

\begin{tabular}{|c|c|c|}
\hline \multicolumn{3}{|c|}{$\begin{array}{l}\text { Table 3. Multivariate logistic regression model for likelihood of } \\
\text { neurologic impairment }\end{array}$} \\
\hline Variables & OR $(95 \% \mathrm{Cl})$ & $p$ \\
\hline Ferritin $\geq 1,150 \mathrm{ng} / \mathrm{mL}$ & $41.4(3.0-563)$ & 0.005 \\
\hline $\begin{array}{l}\text { Duration of midazolam } \\
\text { administration } \geq 7.5 \text { days }\end{array}$ & $37.1(2.9-473)$ & 0.005 \\
\hline Procalcitonin $\geq 1.62 \mathrm{ng} / \mathrm{mL}$ & $13.4(1.5-117)$ & 0.020 \\
\hline D-dimer $\geq 4.5 \mathrm{ug} / \mathrm{mL}$ & $10.2(1.3-80)$ & 0.028 \\
\hline \multicolumn{3}{|c|}{$\begin{array}{l}\text { Cl: Confidence interval, OR: odds ratio. According to cut-off values, age, d-dimer, } \\
\text { ferritin, C-reactive protein, procalcitonin, a dose of midazolam, durations of } \\
\text { midazolam, and fentanyl administrations were added to the multivariate binary } \\
\text { logistic regression model. The Backward method was used in the regression } \\
\text { model and it was not found a significant relationship between the likelihood } \\
\text { of neurologic impairment and each of age, C-reactive protein, durations of } \\
\text { midazolam, and fentanyl administrations }\end{array}$} \\
\hline
\end{tabular}

In this study, the fact that the patients with impaired consciousness were significantly younger $(p=0.002)$ than the patients without impaired consciousness, as well as the fact that their inflammatory parameters were significantly higher, was not surprising because the decline of the immune system with age is typically reflected in a poorer response to infectious diseases (13). This could explain the uncontrolled inflammatory response seen in younger people in response to COVID-19. Yet, a younger age alone cannot always be associated with neurological complications. In fact, the immune system dysfunction seems to be somehow aggravated, possibly due to genetic factors yet to be described.

It must be acknowledged that this study had a number of limitations. First, the study had a retrospective and multicenter design, which meant that subclinical cases were not examined further. Second, the study included only a limited number of ICU patients and a limited number of patients who underwent cranial MRI and LP.

\section{Conclusion}

The use of sedative agents may not always be responsible for patients' delayed recovery from deep sedation. When other causes have been excluded, the possibility of neurological complications should be strongly considered. Moreover, all patients with severe COVID-19 should be screened for signs of hyperinflammation due to the associated risk of neurological complications. The early detection of at-risk cases and the prompt initiation of specific treatment could result in better disease outcomes. However, larger prospective studies are required to confirm the findings of the present study.

\section{Ethics}

Ethics Committee Approval: The study was approved by both the Republic of Turkey Ministry of Health and the Ethics Committee of Acıbadem University (decision no: 202009/12, date: 21.05 .2020 ).

Informed Consent: Retrospective study.

Peer-review: Externally peer-reviewed.

\section{Authorship Contributions}

Surgical and Medical Practices: L.D., N.A., Z.T.S., O.M., C.A., S.D.K., B.G., A.D., S.K., I.Ö.A., Concept: L.D., N.A., Z.T.S., S.D.K., B.G., A.D., I.Ö.A., Design: L.D., N.A., D.K., Z.T.S., S.D.K., B.G., I.Ö.A., Data Collection or Processing: L.D., N.A., Z.T.S., O.M., C.A., Ş.B.D., F.T., F.E.G., S.D.K., B.G., A.D., I.Ö.A., Analysis or Interpretation: L.D., N.A., D.K., B.G., A.D., S.K., I.Ö.A., Literature Search: L.D., N.A., D.K., B.G., A.D., S.K., I.Ö.A., Writing: L.D., N.A., D.K., B.G., I.Ö.A.

Conflict of Interest: No conflict of interest was declared by the authors.

Financial Disclosure: The authors declared that this study received no financial support. 


\section{References}

1. Helms J, Kremer S, Merdji H, ClereJehl R, Schenck M, Kummerlen C, et al. Neurologic Features in Severe SARS-CoV-2 Infection. N Engl J Med 2020;382:2268-70.

2. Kandemirli SG, Dogan L, Sarikaya ZT, Kara S, Akinci C, Kaya D, et al. Brain MRI Findings in Patients in the Intensive Care Unit with COVID-19 Infection. Radiology 2020;297:E232-5.

3. Dogan L, Kaya $D$, Sarikaya $T$, Zengin $R$, Dincer A, Akinci IO, et al. Plasmapheresis treatment in COVID-19-related autoimmune meningoencephalitis: Case series. Brain Behav Immun 2020;87:1558.

4. Kaur SP, Gupta V. COVID-19 Vaccine: A comprehensive status report. Virus Res 2020;288:198114.

5. Sanders JM, Monogue ML, Jodlowski TZ, Cutrell JB. Pharmacologic Treatments for Coronavirus Disease 2019 (COVID19): A Review. JAMA 2020;323:1824-36.

6. Alhazzani W, Møller MH, Arabi YM, Loeb M, Gong MN, Fan E, et al. Surviving Sepsis Campaign: Guidelines on the Management of Critically III Adults with Coronavirus Disease 2019 (COVID-19). Crit Care Med 2020;48:e440-69.

7. Bykowski J, Kruk P, Gold JJ, Glaser CA, Sheriff H, Crawford JR. Acute pediatric encephalitis neuroimaging: singleinstitution series as part of the California encephalitis project. Pediatr Neurol 2015;52:606-14.

8. Mehta P, McAuley DF, Brown M, Sanchez E, Tattersall RS, Manson JJ; HLH Across Speciality Collaboration, UK. COVID-19: consider cytokine storm syndromes and immunosuppression. Lancet 2020;395:1033-4.

9. Baig AM, Khaleeq A, Ali U, Syeda $\mathrm{H}$. Evidence of the COVID-19 Virus
Targeting the CNS: Tissue Distribution, Host-Virus Interaction, and Proposed Neurotropic Mechanisms. ACS Chem Neurosci 2020;11:995-8.

10. Rosário C, Zandman-Goddard G, Meyron-Holtz EG, D'Cruz DP, Shoenfeld Y. The hyperferritinemic syndrome: macrophage activation syndrome, Still's disease, septic shock and catastrophic antiphospholipid syndrome. BMC Med 2013;11:185.

11. Agmon-Levin N, Rosário C, Katz BS, Zandman-Goddard G, Meroni P, Cervera $R$, et al. Ferritin in the antiphospholipid syndrome and its catastrophic variant (cAPS). Lupus 2013;22:1327-35.

12. Meisner M. Update on procalcitonin measurements. Ann Lab Med 2014;34:263-73.

13. Castelo-Branco C, Soveral I. The immune system and aging: a review. Gynecol Endocrinol 2014;30:16-22. 